J. Clin. Chem. Clin. Biochem.

Vol. 20, 1982, pp. 61-63

\title{
A Case of Rare Heterozygous $\alpha_{1}$-Antitrypsin Phenotype: IS
}

\author{
By K. Bencze and X. Baur
}

Institut und Poliklinik für Arbeitsmedizin (Director: Prof. Dr. G. Fruhmann), Pulmonary Section

(Head: Prof. Dr. G. Fruhmann), Medical Clinic I (Director: Prof. Dr. G. Riecker), Klinikum Großhadern, University of Munich

(Received July 14/October 16,1981 )

Summary: We describe a case of the heterozygous antitrypsin phenotype IS. The 20 years old female employee had been recurrently suffering from cutaneous vasculitis over a period of three years. Serum trypsin inhibitor was found to be high ( $1394 \mathrm{ImU}$ ) during the acute stage of the disease. No other serological or physical abnormalities were detected. A relationship between certain $\mathrm{Pi}$ (the term $\mathrm{Pi}$ indicating protease inhibitor $=\alpha_{1}$-antitrypsin) alleles and vasculitis is possible but not certain, as three out of four other patients with this disease were MM phenotypes, the other one being MS type.

\section{Fall eines seltenen heterozygoten $\alpha_{1}$-Antitrypsin-Phänotyps: IS}

Zusammenfassung: Wir beschreiben einen Fall des heterozygoten Phänotyps des $\alpha_{1}$-Antitrypsins IS. Die 20 Jahre alte Patientin erkrankte in den letzten drei Jạhren in unregelmäßigen Abständen an einer cutanen Vasculitis. Die Serumhemmkapazität gegen Trypsin war während der akuten Phase der Krankheit hoch (1394 ImU). Es wurden keine anderen serologischen oder physischen Abnormitäten beobachtet. Eine Beziehung zwischen besonderen $\mathrm{Pi}\left(=\right.$ Proteaseinhibitor $=\alpha_{1}$-Antitrypsin)-Allelen und Vasculitis ist möglich, aber nicht sicher, da von vier anderen Patienten mit dieser Krankheit drei zu den MM-Phänotypen und einer zu den MS-Typen gehörten.

\section{Introduction}

It is well known that individuals homozygous with respect to the $\alpha_{1}$-antitrypsin allele $Z$ have an increased risk of panacinar emphysema, chronic obstructive pulmonary disease, liver cirrhosis and malignant hepatoma (1-5).

Reports concerning the pathological role of the heterozygous $\alpha_{1}$-antitrypsin $M Z$ and MS variaints are controversial; some studies suggest a relationship to pulmonary diseases, others do not $(6-11)$. There is evidence that heterozygosity may become a deciding pathological factor in the presence of additional pulmonary risks like smoking, exposure to industrial dusts, fumes and/or individual predisposition, e.g. abnormal enzyme patterns $(10,11)$.

From the genetic point of view it is possible for $25 \%$ of children from heterozygous parents to have the homozygous SS or ZZ type, whereas the other $50 \%$ will be in danger having heterozygous variants (9).
As opposed to the MŻ and MS types, which have been the subject of several studies, certain rare variants can be described only in the form of case reports.

\section{Case History and Results of Laboratory Investigations}

For the last three years the 20 year old female employee has suffered recurrently from raised, erythematous cutaneous lesions, which developed simultaneously on average once to four times every 6 weeks. These eruptions were predominantly localized symmetrically on the lower extremities and were accompanied by marked swelling of feet, malleolar regions and lower legs. They also disappeared spontaneously within a week without treatment, or even within few days if corticosteroids were administered. Skin biopsy specimens showed mixed cellular infiltrate of blood vessels (neutrophils, lymphocytes and monocytes), nuclear debris and erythrocy te extravasation. In direct immunoflourescence studies there was strong evidence for deposition of immune complexes in vascular lesions (deposition of C 3, IgM and fibrin in the walls of superficial dermal venules).

Immune complexes, antinuclear antibodies, or rheumatoid factors were not detectable in the serum; C 3, C 4, C 5, C 1 inhibitor, bilirubin, prothrombin, aspartate aminotransferase, alanine 
aminotransferasc, $\gamma$-glutamyltransferase, alkaline phosphatase and cholinesterase, and erythrocyte sedimentation rate were within normal ranges.

Extensive clinical and laboratory investigations including pulmonary function tests suggested no further organic abnormalities, except chronic tonsillitis. The etiology of the disease remained unknown; intracutancous and epidermal skin tests with a battery of allergens were negative. Interruption of oral contraceptives, the only drugs the patient took, led to no changes in the symptoms described.

\section{Methods}

The $\alpha_{1}$-antitrypsin phenotypes were determined by isoelectric focusing on polyacrylamide gel slabs. As previously described (12), $20 \mu$ l of each serum was added to specially prepared gel slabs of $1 \mathrm{~mm}$ thickness.

Serum trypsin inhibitory capacity

Quantitative functional analyses of serum $\alpha_{1}$-antitrypsin were performed according to the method of Fritz et.al. (13). One inhibitor milliunit (ImU) is defined as reduction of the trypsincatalyzed hydrolysis of the substrate $\mathrm{N}-\alpha$-benzyl- $L$-arginine$p$-nitroanilide by $1 \mu \mathrm{mol}$ per $\min (\Delta \mathrm{A}=0.00332$ in $3 \mathrm{mil}$ solvent $)$.

\section{Results}

Using $M_{1} M_{2}$ standardized sera and reference sera of subjects with $M_{1} S$ and $M_{1} I$ phenotypes the rare phenotype IS was identified (fig. 1). Additional support for these results was obtained by a family study, which

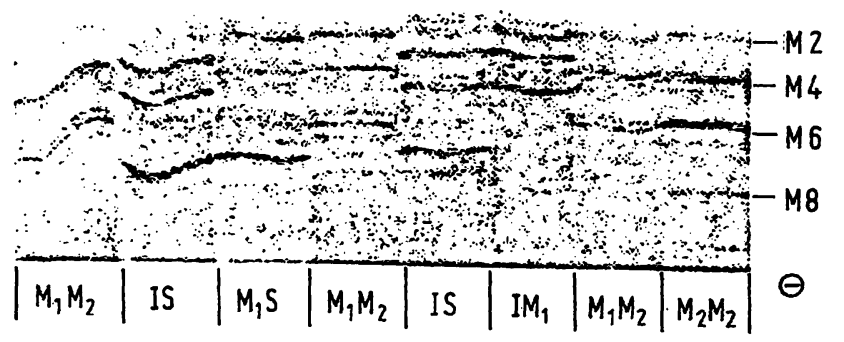

Fig. 1. Phenotyping of $\alpha_{1}$-antitrypsin variants IS, MS and MI on polyacrylamide gel.

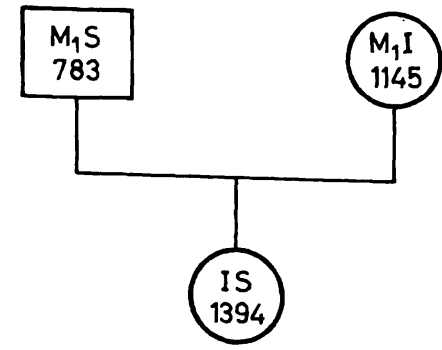

Fig. 2. Family pedigree of propositus protein inhibitor IS: phenotypes and serum trypsin inhibitory capacities. showed that the parents of the patient have $M_{1} I$ and $M_{1} S$ phenotypes (fig. 2). Serum trypsin inhibitory capacity was normal in the mother's serum (1145 ImU; normal range for IM-types $1150 \pm 180 \mathrm{ImU}$ ), decreased in the father's serum (783 ImU; normal ranges for MStypes: $1060 \pm 180 \mathrm{ImU}$ ), but rather high in the serum of the above mentioned patient (1394 ImU).

\section{Discussion}

Many studies on the distribution of $\alpha_{1}$-antitrypsin phenotypes in different populations have been published. Based upon the mean gene frequency from the studies mentioned in table 1 we calculated a frequency of the heterozygous variant IS of 8.6 in 100000 .

Tab. 1. Pi allele frequencies in some European and non European populations.

\begin{tabular}{|c|c|c|c|c|c|c|}
\hline \multirow{2}{*}{$\begin{array}{l}\text { Ref. } \\
\text { No. }\end{array}$} & \multirow[t]{2}{*}{ Year } & \multirow[t]{2}{*}{ Countriy } & \multirow{2}{*}{$\begin{array}{l}\text { Ob- } \\
\text { served }\end{array}$} & \multicolumn{3}{|c|}{ Gene frẹueñucies } \\
\hline & & & & $S$ & I & $\underline{Z}$ \\
\hline 8 & 1975 & England & 4042 & 0.0500 & 0.0000 & 0.014 \\
\hline 15 & 1972 & Fra & 520 & 0.06 & 0.0006 & 0.05 \\
\hline 6 & 1975 & Fran & & 0 & 00 & 0.0 \\
\hline 17 & 1977 & Fran & 1653 & 0.0713 & 0.0036 & 0.0142 \\
\hline 18 & $197 ?$ & Fran & & 0.0750 & 0.0018 & 0.0232 \\
\hline 19 & 1970 & Germany & & 0.0 & 0. & 0.0087 \\
\hline 20 & 1977 & Germ & 5 & 0.0 & & 0.0 \\
\hline 11 & 1980 & Germa & 280 & 0.0300 & 0.0018 & 0.0140 \\
\hline 1 & 1975 & Netherlands & 1474 & 0.0 & 0.0014 & 0.0123 \\
\hline 2 & 1977 & Netherlands & 708 & & & 0.0049 \\
\hline 9 & 1970 & Hungary & 172 & 0.0 & & 0.0 \\
\hline 23 & 1975 & Ireland & 1000 & 0.0 & $0 ! 0$ & 0.0200 \\
\hline 24 & 1978 & Italy & 202 & 0.0297 & $\dot{0}: 0$ & $0: 0099$ \\
\hline 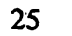 & 1978 & Italy & & & & 0.0150 \\
\hline 26 & 1967 & Norway & 1967 & 0.0 & & 0.0157 \\
\hline 27 & 1979 & Norw & 12 & 00 & 38 & 0.0246 \\
\hline מר & 1976 & Portugal & $\overline{3} 30$ & 0.1152 & 0.0015 & 0.0182 \\
\hline & & Somalia & & 0.0144 & 0.0014 & 0.0072 \\
\hline & 1968 & Spain & n & 0.1124 & 0.0013 & 0.0119 \\
\hline
\end{tabular}

It remains to be proven if there is a relationship between: IS type and other Pi types on the one hand and the occurrence of immune complex vaculitis on the other hand. In order to clarify this question, screening studies of patients with this disease seem to be necessary. Our preliminary studies showed that three out of four patients with strong evidence for immune complex vasculitis (identification of deposits of immunoglobulins and $C 3$ within and around venules of dermál lesions) were of the MM type and the fourth one of this group belonged to the $\mathrm{M}_{1} \mathrm{~S}$ type. Furthermore, three out of the latter group also had significantly elevated serum trypsin inhibitory capacities (> $1499 \mathrm{ImU})$.

It is well known that $\alpha_{1}$-antitrypsin behaves as an acute phase reactant and that it's serum concentration increases during inflammation. This may be the cause of the elevated serum trypsin inhibitory capacity values in patients with acute stages of vasculitis. 


\section{References}

1. Sharp, H. L., Bridges, R. A., Krivit, W. \& Freier, E. F. (1969) J. Lab. Clin. Med. 73, 934-939.

2. Mittman, C., Liebermann, J., Marasso, F. \& Miranda, A. (1971) Chest 60, 214-221.

3. Berg, N. O. \& Erikson, S. (1972) New Engl. J. Med. 287, 1264-1267.

4. Kueppers, F. \& Black, L. F. (1974) Am. Rev. Resp. Dis. $110,176-194$.

5. Liebermann, J. (1976) N.Y. State Med. 76, 181-186.

6. Buist, A. S., Sexton, G. J., Abdul-Mordy, H. Azzam \& Adams, B. E. (1979) Am. Rev. Respir. Dis. 120, 759-766.

7. McDonough, D. J., Nathan, S. P., Knudson, R. J. \& Lebowitz, M.D. (1979) J. Clin. Invest. 63, 299-309.

8. Cox, D. W., Hoeppner, V. H. \& Levison, H. (1976) Am. Rev. Respir. Dis. 113,601-606.

9. Osswald, P. \& Gathmann, H. (1979) Leber, Magen, Darm 9, 241-246.

10. Evans, H. E. \& Bognacki, N. (1979) Envir. Health Persp. 29, $57-61$.

11. Bencze, K., Sabatke, L. \& Fruhmann, G. (1980) Chest 77, $761-763$.

12. Bencze, K. \& Sabatke, L. (1980) J. Clin. Chem. Clin. Biochem. $18,13-16$.

13. Fritz, H., Trautschold, I. \& Werle, E. (1970) in Methoden der enzymatischen Analyse, pp. 1023-1029 (Bergmeyer H. U., ed.) Verlag Chemie; Weinheim.

14. Cook, P. J. L. (1975) Ann. Hum. Genet. 38, 275-289.

15. Robinet-Levy, M. \& Rieunier, M. (1972) Revue Fr. Trasfus. $15,61-72$.

16. Morin, T., Martin, J. P., Fedelman, G., Rueff, B., Benhamer, J. P. \& Ropatz, C. (1975) Lancet II, 250-251.
17. Arnaud, P., Chapius-Cellier, C., Vittoz, P. \& Creyssel, R. (1977) Hum. Genet. 39, 63-68.

18. Sesboüe, R., Charlionet, R., Vercaigne, D., Giumbretiere, J. \& Martin, J. P. (1978) Hum. Hered. 28, 280-284.

19. Kellerman, H. \& Walter, H. (1970) Hum. Genet. 10, $145-150$.

20. Genz, T., Martin, J. P. \& Cleve, H. (1977) Hum. Genet. 38, $325-332$.

21. Hoffmann, J. J. M. L. \& van den Broek, W. G. M. (1975) Hum. Genet. 32, 43-48.

22. Klasen, E. C., Franken, C., Volkers, V. S. \& Bernini, L. F. (1977) Hum. Genet. 37, 303-313.

23. Blundell, G., Frazer, A., Cole, R. B. \& Nevin, N. C. (1975) Ann. Hum. Genet. 38, 289-344.

24. Klasen, E. C., D'Andrea, F. \& Bernini, L. F. (1978) Hum. Hered. 28, 474-478.

25. Piantelli, M., Auconi, P. \& Musiani, P. (1978) Hum. Hered. $28,468-473$.

26. Fagerhol, M. K. (1967) Acta Pathol. Microbiol. Scand. 70, 421-428.

27. Gulsiuk, A. \& Fagerhol, M. K. (1979) Scand. J. Respir. Dis. $60,267-274$.

28. Martin, J. P., Sespone, R., Charlionet, R., Ropartz, C. \& Pereira, M. T. (1976) Hum. Hered. 26, 310-314.

29. Massi, G. \& Vecchio, M. F. (1977) Hum. Genet. 38, $265-269$.

30. Fagerhol, M. K. \& Tenfjord, O.W. (1968) Acta Pathol. Microbiol. Scand. 72, 601-608.

Dr. K. Bencze

Institut und Poliklinik für Arbeitsmedizin der Universität

Ziemssenstr. 1

D-8000 München 2 


i i

